\title{
Sunflower Water Requirements Using Single and Dual Crop Coefficients
}

\author{
Ahmad S. M. Bondok ${ }^{*}$, G. Abdel-Nasser ${ }^{*}$ and F. I. Radwan ${ }^{* *}$ \\ "Soil and Agricultural Chemistry Dept., Faculty of Agriculture Saba Basha, Alexandria \\ University, EGYPT \\ **Plant Production Dept., Faculty of Agriculture Saba Basha, Alexandria University, \\ EGYPT
}

\begin{abstract}
A field experiment of drip-irrigated Sunflower (Helianthus annuus) was conducted at the Experimental Farm, Faculty of Agriculture (Saba-Basha), Alexandria University, Egypt during 2013 growing season to develop seasonal $\mathrm{K}_{\mathrm{c}}$ values for drip irrigated sunflower. In this context the objectives were:

1. to analyze the ability of the FAO-56 single and dual crop coefficient models for assessment the regional evapotranspiration and water requirements, 2. to estimate an adequate water quantity needed for the sunflower.

The sunflower variety Sakha 53 was cultivated at $28^{\text {th }}$ April and harvesting was done at 8 August, 2013. Seeds were sown at $4-5$ seeds in each hill with a spacing of $0.3 \mathrm{~m}$ within each row and 0.6 spacing, then thinned to one plant after 2 weeks from sowing. After emergence, the plots were irrigated by the drip irrigation method. All field practices were done as usually recommended for sunflower cultivation. The irrigation treatments based on replenishment of soil water depletion according to reference evapotranspiration $\left(\mathrm{ET}_{0}\right)$. The irrigation treatments were; irrigation at 20, 40, 60,80 and $100 \%$ of $E T_{0}$. The results indicated that seasonal sunflower evapotranspiration $(\mathrm{mm})$ has higher value with field irrigation approach and the lower value was for standard FAO single approach. The seasonal evapotranspiration (single crop coefficient approach) was less than the seasonal evapotranspiration of dual crop coefficient approach. It appears that ETc estimation of sunflower crop is more accurate by dual crop coefficient approach than those produced by single crop coefficient approach because of using more parameters and taking the soil practices and crop characteristics in consideration. The basal crop coefficient values cannot be proposed for all climates and regions because of different climatic conditions and crop management practice under different regions. The present study recommended that for the present conditions and the same other conditions, the irrigation of sunflower crop must be done according to the dual crop coefficient approach because it is more accurate than single crop coefficient and close up to the field conditions.
\end{abstract}

Keywords: sunflower, water requirements, single crop coefficient, dual crop coefficient, FAO Penman- Monteith model

\section{INTRODUCTION}

Water scarcity in semi-arid or arid regions is one of the main factors limiting agricultural development. The impact of such water scarcity is amplified by inefficient irrigation practices. Therefore, the first step toward sound management of the scarce water resources in these regions requires an accurate estimation of the water needs and consumption of irrigated agriculture. Several models have been developed to simulate crop evapotranspiration $\left(E T_{c}\right)$ and in some cases, its components (soil evaporation and plant transpiration). These models ranged from complex (Braud et al., 1995) to more simple and conceptual ones (Olioso et al., 1999). FAO-56 is based on the concepts of reference evapotranspiration $\mathrm{ET}_{0}$ and 
crop coefficients $\mathrm{K}_{\mathrm{c}}$, which have been introduced to separate the climatic demand from the plant response (Allen et al., 1998). There are two approaches to estimate crop evapotranspiration: the single and the dual crop coefficients. In the FAO-56 single crop coefficient approach, the effect of both crop transpiration and soil evaporation are integrated into a single crop coefficient, $\mathrm{K}_{\mathrm{c}}$, the FAO-56 dual crop coefficient approach describes the relationship between maximal evapotranspiration $E T_{c}$ and reference evapotranspiration $E T_{0}$ by separating $K_{c}$ into a basal crop $\left(\mathrm{K}_{\mathrm{cb}}\right)$ and soil water evaporation $\left(\mathrm{K}_{\mathrm{e}}\right)$ coefficients. In the semi-arid Mediterranean region of southern Morocco, Er-Raki et al. (2010) applied the single approach and found that the approach overestimates AET by about $18 \%$ when using the crop coefficient suggested by Allen (2000).

Knowledge of crop coefficient $\left(\mathrm{K}_{\mathrm{c}}\right)$ is essential for the estimation of water use. It helps in determining the water requirement of the crops according to their growth stage and environmental factors. Studies have found that $\mathrm{K}_{\mathrm{c}}$ for the same crop may vary from place to place based on factors such as climate and soil evaporation (Allen et al., 1998; Kang et al., 2003). Doorenboss and Pruitt (1977) and Kang et al. (2003) emphasized the need to develop regional $\mathrm{K}_{\mathrm{c}}$ for accurate estimation of water use, under a specific climatic condition.

Numerous empirical methods have been developed to estimate evapotranspiration from different climatic variables. Examples of such methods include Penman-Monteith (Monteith, 1965) and Blaney-Criddle model (Blaney and Criddle, 1950). Blaney-Criddle model requires the temperature data while the FAOPenman-Monteith requires additional parameters such as wind speed, humidity and solar radiation. The Blaney-Criddle method is used to calculate monthly $\mathrm{K}_{\mathrm{c}}$ values as compared to daily and less data is needed for this method.

The Food and Agricultural Organization (FAO) recommended FAO-Penman Monteith (FAO-PM) method as the sole standard method for computation of $\mathrm{ET}_{0}$ (Allen et al., 1998). FAO-PM can provide accurate $\mathrm{ET}_{0}$ estimates for weekly or even hourly periods.

Accurate prediction of crop water use is the key to develop the efficient irrigation management practices making it imperative to develop $\mathrm{K}_{\mathrm{c}}$ for a specific crop. Doorenbos and Pruitt (1977) prepared a comprehensive list of $\mathrm{K}_{\mathrm{c}}$ for various crops under different climatic conditions by compiling results from different studies. A similar list of $\mathrm{K}_{\mathrm{c}}$ was also given by Allen et al. (1998) and Doorenbos and Kassam (1979). However, $\mathrm{K}_{\mathrm{c}}$ for a crop may vary from one place to another, depending on factors such as climate, soil, crop type, crop variety, irrigation methods (Kang et al., 2003). Thus, for an accurate estimation of the crop water use, it is imperative to use a regional $K_{c}$. Brouwe and Heibloem (1986) stated that the steps for development of $\mathrm{K}_{\mathrm{c}}$ as: determination of the total growing period of the crop, identifying the length of different growth stages, and determination of $\mathrm{K}_{\mathrm{c}}$ 
values for each growth stage. However, $\mathrm{K}_{\mathrm{c}}$ cannot be measured directly, but is estimated as a ratio $\left(E T_{C} / E T_{0}\right)$. While $E_{0}$ can be estimated using one of the several available methods, $\mathrm{ET}_{\mathrm{c}}$ can be estimated by a lysimeter study as reported by Grattan et al. (1998). There are two approaches to estimate crop evapotranspiration: the single and the dual crop coefficients. The FAO-56 dual crop coefficient approach (Allen et al., 1998) describes the relationship between crop evapotranspiration, $\mathrm{ET}_{\mathrm{c}}$ and reference evapotranspiration, $\mathrm{ET}_{0}$ by separating the single $\mathrm{K}_{\mathrm{c}}$ into the basal crop $\mathrm{K}_{\mathrm{cb}}$ and soil water evaporation $\mathrm{K}_{\mathrm{e}}$ coefficients, while in the FAO-56 single crop coefficient approach, the effect of both crop transpiration and soil evaporation are integrated into a single crop coefficient. Many studies have focused on the application of the single approach for determining olive water requirement within Mediterranean regions (Palomo et al., 2002; AbidKarray et al., 2008; Martinez-Cob and Faci, 2010). In the semi-arid Mediterranean region of southern Morocco, Er-Raki et al. (2008) applied also the single approach over the same study site of this work, and they found that the approach overestimates AET by about $18 \%$ when using the crop coefficient suggested by Allen et al. (1998). Recently, several studies used the FAO-56 dual crop coefficient for estimating water consumptions of different crops (Hunsaker et al., 2003, 2005; Allen et al., 2005 a, b; Paço et al., 2006; Er-Raki et al., 2007). Some of these studies adopted the FAO-56 dual approach to use satellite-based vegetation index (Hunsaker et al., 2003, 2005; Er-Raki et al., 2007; González-Dugo and Mateo, 2008; Er-Raki et al., 2010). The results show that relating the basal crop coefficient $K_{c b}$ to remotely sensed vegetation index greatly improves the performance of the FAO-56 method. However, Er-Raki et al. (2006) showed that the performance of the FAO-56 method has some limitations when there is high soil evaporation or when stress occurs. To overcome this problem and then enhance the FAO-56 performances, ET derived from thermal infrared (TIR) observations was assimilated into FAO-56 single source model (Er-Raki et al., 2008) in order to estimate accurately the water consumption of olive orchards in the semi-arid region of the Ten sift basin (central of Morocco).

The goal of this study was to develop seasonal and growth stages $\mathrm{K}_{\mathrm{c}}$ values for drip irrigated sunflower. In this context the objectives of this study were:

1. to analyze the ability of the FAO-56 dual crop coefficient model for assessment the regional evapotranspiration and water requirements.

2. to estimate an adequate water quantity needed for the sunflower and to determine the best quantity of irrigation by using the FAO- single and dual crop coefficient approaches.

\section{MATERIALS AND METHODS}

\section{Experimental site and conditions}

This study was conducted during the 2013 summer season at the Experimental Farm, Faculty of Agriculture (Saba-Basha), Alexandria University, 
Egypt. The farm is located at Abees region located at $31^{\circ} 10.102^{\prime} \mathrm{N}$ and $29^{\circ}$ $58.085^{\prime} \mathrm{E}$ with an altitude of $(-5 \mathrm{~m})$ under sea level. The site was planted with corn crop in the previous season. This area is characterized by a semi-arid climate, the weather is hot and dry from May to August where temperatures ranged from 25 to $30^{\circ} \mathrm{C}$. On the other hand, the average values of rainfall were $186.2 \mathrm{~mm}$ per year. Wind speed average was $13.5 \mathrm{~km} /$ day and relative humidity average was about $69.5 \%$. Some climatologically data on the experimental site were taken from Nouzha Weather Station and are given in Table (1).

\section{Soil of the experimental site}

Soil samples were collected from the experimental soil for both surface (0$30 \mathrm{~cm})$ and subsurface $(30-60 \mathrm{~cm})$ layers. Some physical and chemical properties of the experimental field soil are presented in Table (2). The soil properties were performed according to the methods outlined in Carter and Gregorich (2008). The soil of the experimental site is clayey texture with water table level of $1 \mathrm{~m}$ down the soil surface, the groundwater is moderately saline $(2.5 \mathrm{dS} / \mathrm{m})$ and the contribution of water table to plant water requirements is low in the site of experiment.

\section{Sunflower cultivation}

Sunflower (Helianthus annuus) variety Sakha 53 early variety (100 days' crop age) was selected for the study at 2013 summer season. Plant sowing date was at 28 April, 2013. Seeds were sown (4-5 seeds) in each hill with spacing of 0.3 $\mathrm{m}$ within each row. Thinning to one plant per hill was carried out after 15 days from sowing to obtain a final plant population of 55500 plants/ha. After emergence, the plots were irrigated by the drip irrigation method, Table (3) shows the chemical analysis of irrigation water. Irrigation was terminated at 5 August, complete canopy and initial blooming date was at 13 June, and harvesting data was at 9 August. All field practices were done as usually recommended for sunflower cultivation. Phosphorus fertilizer as calcium superphosphate $\left(15.5 \% \mathrm{P}_{2} \mathrm{O}_{5}\right)$ was fully added to the soil during seed preparation at $336 \mathrm{~kg} \mathrm{P}_{2} \mathrm{O}_{5} \mathrm{ha}^{-1}$. Ammonium Nitrate $(33.5 \% \mathrm{~N})$ at the rate of $168 \mathrm{~kg} \mathrm{ha}^{-1}$ were applied at two equal doses, one after sowing and the second after one month later. Potassium Sulfate $\left(48 \% \mathrm{~K}_{2} \mathrm{O}\right)$ at the rate of $67 \mathrm{~kg}$ $\mathrm{ha}^{-1}$ were added at two equal doses, one after sowing and the second after one month later. 
Table (1). Daily maximum, minimum and average temperature, wind speed, solar radiation for the experimental Site during the experimental period

\begin{tabular}{lcccccccc}
\hline Months & $\begin{array}{c}\text { Average } \\
\text { minimum } \\
\text { daily } \\
\text { temperature } \\
\mathbf{T}_{\min }\left({ }^{\circ} \mathbf{C}\right)\end{array}$ & $\begin{array}{c}\text { Average } \\
\text { maximum } \\
\text { daily } \\
\text { temperature } \\
\mathbf{T}_{\max }\left({ }^{\circ} \mathbf{C}\right)\end{array}$ & $\begin{array}{c}\text { Average } \\
\text { daily } \\
\text { temperature } \\
\mathbf{T}_{\mathbf{m}}\left({ }^{\circ} \mathbf{C}\right)\end{array}$ & $\begin{array}{c}\text { Average } \\
\text { daily wind } \\
\mathbf{s p e e d} \\
\mathbf{U}_{\mathbf{2}}(\mathbf{m} / \mathbf{s})\end{array}$ & $\begin{array}{c}\text { Average } \\
\text { relative } \\
\text { humidity } \\
\%\end{array}$ & $\begin{array}{c}\text { Average } \\
\text { atmospheric } \\
\text { pressure } \\
\mathbf{m b}\end{array}$ & $\begin{array}{c}\text { Average } \\
\text { precipitation } \\
\mathbf{m m} / \mathbf{m o n t h}\end{array}$ & $\begin{array}{c}\text { Average } \\
\text { daily solar } \\
\text { radiation } \\
\left(\mathbf{M J} / \mathbf{m}^{2} / \mathbf{d a y}\right)\end{array}$ \\
\hline April 2013 & 14.8 & 24.6 & 19.4 & 11.18 & 62.9 & 1014.8 & 0 & 34.12 \\
May 2013 & 18.8 & 28.7 & 23.5 & 9.79 & 68.0 & 1012.4 & 3.1 & 35.90 \\
June 2013 & 21.7 & 30.3 & 25.6 & 10.83 & 68.4 & 1011.1 & 0 & 37.41 \\
July 2013 & 23.4 & 30.2 & 26.6 & 11.66 & 71.4 & 1008.1 & 0 & 36.64 \\
August 2013 & 23.9 & 31.7 & 27.8 & 9.58 & 72.1 & 1008.9 & 0 & 34.99 \\
\hline
\end{tabular}


Table (2). Some physical and chemical properties of the experimental site

\begin{tabular}{|c|c|c|c|c|}
\hline Soil parameters & $\begin{array}{l}0-10 \mathrm{~cm} \\
\text { depth }\end{array}$ & $\begin{array}{l}10-20 \mathrm{~cm} \\
\text { depth }\end{array}$ & $\begin{array}{l}20-40 \mathrm{~cm} \\
\text { depth }\end{array}$ & Unit \\
\hline \multicolumn{5}{|c|}{ Particle size distribution(\%) } \\
\hline Sand & 29.7 & 29.7 & 32.2 & $\%$ \\
\hline Silt & 15.0 & 17.5 & 15.0 & $\%$ \\
\hline Clay & 55.3 & 52.8 & 52.8 & $\%$ \\
\hline Textural class & Clay & Clay & Clay & - \\
\hline Soil bulk density & 1.240 & 1.245 & 1.248 & $\mathrm{Mg} /$ \\
\hline $\begin{array}{l}\text { Soil moisture content at field capacity }\left(\theta_{\mathrm{fc}}\right) \\
\text { Soil moisture content at permanent wilting point }\left(\theta_{\mathrm{wp}}\right)\end{array}$ & $\begin{array}{l}0.3513 \\
0.1221\end{array}$ & $\begin{array}{l}0.3613 \\
0.1281\end{array}$ & $\begin{array}{l}0.3687 \\
0.1295\end{array}$ & $\begin{array}{l}m^{3} m^{-} \\
m^{3} m^{-}\end{array}$ \\
\hline Plant available water content (PAW) & 0.2292 & 0.2332 & 0.2392 & $\mathrm{~m}^{3} \mathrm{~m}^{-}$ \\
\hline Organic matter content & 2.87 & 2.87 & 2.15 & $\hat{\%}$ \\
\hline Total calcium carbonate & 18.12 & 18.12 & 15.78 & $\%$ \\
\hline Electrical Conductivity $\left(E C_{w}\right),(1: 1$, soil: water extract) $d S / m$ & 6.98 & 6.29 & 5.94 & $\mathrm{ds} / \mathrm{m}$ \\
\hline $\mathrm{pH}(1: 1$, soil : water suspension $)$ & 8.05 & 8.15 & 8.25 & - \\
\hline \multicolumn{5}{|l|}{ Soluble Cations } \\
\hline $\mathrm{Ca}^{2+}$ & 2.38 & 1.69 & 1.42 & meq/ \\
\hline $\mathrm{Mg}^{2+}$ & 7.85 & 6.05 & 4.50 & meq/ \\
\hline $\mathrm{Na}^{+}$ & 58.15 & 54.13 & 52.13 & meq/ \\
\hline $\mathrm{K}^{+}$ & 1.35 & 1.12 & 1.12 & meq/ \\
\hline \multicolumn{5}{|l|}{ Soluble Anions } \\
\hline $\mathrm{CO}^{=}{ }_{3+} \mathrm{HCO}^{-3}$ & 10.20 & 9.92 & 2.12 & meq/ \\
\hline $\mathrm{Cl}^{-}$ & 44.00 & 44.39 & 41.00 & meq/ \\
\hline $\mathrm{SO}_{4}{ }_{4}$ & 14.03 & 7.70 & 12.54 & meq/ \\
\hline
\end{tabular}

Table (3). Chemical analysis of irrigation water used in the field experiment

\begin{tabular}{|c|c|c|}
\hline Parameters & Value & unit \\
\hline $\mathrm{pH}$ & 7.35 & \\
\hline $\mathrm{EC}_{\mathrm{iw}}$ & 0.60 & $\mathrm{dSm}^{-1}$ \\
\hline \multicolumn{3}{|c|}{ Soluble Cations } \\
\hline $\mathrm{Ca}^{+2}$ & 1.89 & meql $^{-1}$ \\
\hline $\mathrm{Mg}^{+2}$ & 0.81 & meql $^{-1}$ \\
\hline $\mathrm{K}^{+}$ & 2.74 & meql $^{-1}$ \\
\hline $\mathrm{Na}^{+}$ & 0.46 & meql $^{-1}$ \\
\hline \multicolumn{3}{|c|}{ Soluble Anions } \\
\hline $\mathrm{CO}_{3}{ }_{3}+\mathrm{HCO}_{3}^{-}$ & 1.98 & $\mathrm{meql}^{-1}$ \\
\hline & 0.810 & meql $^{-1}$ \\
\hline $\mathrm{SO}_{4}^{-2}$ & 3.14 & meql $^{-1}$ \\
\hline
\end{tabular}


At harvest, the sample of plants $(1 \mathrm{~m}$ of the row $\times 0.60 \mathrm{~m}$ width of the row $=$ $0.60 \mathrm{~m}^{2}$ ) of the two central ridge were chosen to determine the sunflower yield and the total yield per ha ${ }^{-1}$ was calculated.

\section{Irrigation regime}

The irrigation treatments were based on replenishment of soil water depletion according to the reference evapotranspiration $\left(E T_{0}\right)$. The irrigation treatments were:

I1 irrigation at $20 \%$ of $\mathrm{ET}_{0}$,

12 irrigation at $40 \%$ of $\mathrm{ET}_{0}$,

13 irrigation at $60 \%$ of $\mathrm{ET}_{0}$,

14 irrigation at $80 \%$ of $\mathrm{ET}_{0}$, and

15 irrigation at $100 \%$ of $\mathrm{ET}_{0}$

Irrigation water in drip irrigation system was taken by a water pump. Distribution lines consisted of PVC pipe manifolds for each plot. The diameter of the polyethylene laterals was $16 \mathrm{~mm}$ and each lateral irrigated one plant row. The inline emitter discharge rate was $4 \mathrm{I} \mathrm{h}^{-1}$ at $100 \mathrm{kPa}$ operating pressure. The actual emitter discharge rate was calibrated before starting the experiment. The drip network calibration was performed and the actual rate of emitter was $3.43 \mathrm{I} \mathrm{h}^{-1}$.

Soil water content was measured by sampling a soil from each row with soil tube $0.025 \mathrm{~m}$ diameter at three depths i.e. $0-10,10-20$ and 20-60 cm below soil surface then determined by gravimetric method. Soil water contents were monitored prior each irrigation and after irrigation at surface and subsurface depths through electronic pressure transducer (electronic tensimeter).

\section{Crop Evapotranspiration}

The irrigation requirements were calculated according to the PenmanMonteith equation (Allen et al., 1998) according the following equation:

$$
\mathrm{ET}_{\text {crop }}=\frac{\mathrm{ET}_{\text {drip }}}{\mathrm{E}_{\mathrm{a}}(1-\mathrm{LR})}
$$

Where:

$\mathrm{ET}_{\text {crop }}$ is the crop evapotranspiration, $\mathrm{mm}$ /day

$\mathrm{ET}_{\text {drip }}$ is the crop evapotranspiration under drip irrigation system, $\mathrm{mm} / \mathrm{day}$

$E_{a}$ is the efficiency of irrigation system (assumed as $95 \%$ for drip irrigation system under the present conditions).

LR is the Leaching Requirements required for salt leaching in the root zone depth (assumed as $15 \%$ ). and

$\mathrm{ET}_{\text {drip }}=\mathrm{K}_{\mathrm{r}} \times \mathrm{K}_{\mathrm{c}} \times \mathrm{ET}_{0}$

$\mathrm{K}_{\mathrm{r}}$ is the reduction factor that reflects the percent of soil covering by crop canopy and can be calculated by the equation described in Karmeli and Keller (1975): 


$$
\mathrm{K}_{\mathrm{r}}=\frac{\mathrm{GC}}{0.85}
$$

Where, GC is the ground cover fraction (plant canopy area divided by soil area occupied by one plant, assumed as 0.6 ).

$\mathrm{K}_{\mathrm{c}}$ is the crop coefficient ranging from 0.35 (for initial stage) to 1.15 (for development stage) for sunflower (Allen et al., 1998). We need the length and crop coefficient $\left(\mathrm{K}_{\mathrm{c}}\right)$ for each of the 4 growth stages: initial, crop development, midseason and late season stages. The crop coefficients $\left(\mathrm{K}_{\mathrm{c}}\right.$ and $\left.\mathrm{K}_{\mathrm{cb}}\right)$ were collected from FAO (Allen et al., 1998) and are presented in Table (4).

Table (4). Crop coefficient $\left(\mathrm{K}_{\mathrm{c}}\right)$ and development stages period for sunflower

\begin{tabular}{lccc}
\hline Growth stages & $\begin{array}{c}\mathbf{K}_{\mathrm{c}} \\
\text { Single crop } \\
\text { coefficient }\end{array}$ & $\begin{array}{c}\mathbf{K}_{\mathrm{cb}} \\
\text { Basal Crop } \\
\text { Coefficient }\end{array}$ & $\begin{array}{c}\text { Stage } \\
\text { period, } \\
\text { days }\end{array}$ \\
\hline Initial & 0.35 & 0.15 & 20 \\
Crop development & $0.35-1.15$ & $0.15-1.05$ & 25 \\
Mid-season & 1.15 & 1.05 & 38 \\
Late-season & $1.15-0.35$ & $1.05-0.2$ & 20 \\
\hline
\end{tabular}

$\mathrm{ET}_{0}$ is the reference evapotranspiration calculated with FAO PenmanMonteith equation (Allen et al., 1998) using the climatic data collected from the Nouzha Weather Station as follows:

$$
E T_{0}=\frac{0.408 \Delta\left(R_{n}-G\right)+\gamma \frac{900}{T+273} U_{2}\left(e_{s}-e_{a}\right)}{\Delta+\gamma\left(1+0.34 U_{2}\right)}
$$

Where:
$\mathrm{ET}_{0}$
Reference evapotranspiration, $\mathrm{mm}$ day $^{-1}$
$\mathbf{R}_{\mathbf{n}} \quad$ Net radiation at the crop surface, $\mathrm{MJ} \mathrm{m}^{-2}$ day $^{-1}$,
G Soil heat flux density, $\mathrm{MJ} \mathrm{m}^{-2}$ day $^{-1}$, Generally very small and assumed to be zero).
T Mean daily air temperature at $2.0 \mathrm{~m}$ height, ${ }^{\circ} \mathrm{C}$,
$\mathbf{U}_{2} \quad$ Wind speed at $2 \mathrm{~m}$ height, $\mathrm{m} \mathrm{s}^{-1}$,
$\mathbf{e}_{\mathrm{s}} \quad$ Saturation vapor pressure at 1.5 to $2.5-\mathrm{m}$ height, $\mathrm{kPa}$,
$\mathbf{e}_{\mathrm{a}} \quad$ Actual vapor pressure at 1.5 to $2.5-\mathrm{m}$ height, $\mathrm{kPa}$,
$\mathbf{e}_{\mathbf{s}}-\mathbf{e}_{\mathbf{a}} \quad$ Saturation vapor pressure deficit, $\mathrm{KPa}$,
$\Delta \quad$ Slope vapor pressure curve, $\mathrm{kPa}^{\circ} \mathrm{C}^{-1}$,
$\gamma \quad$ Psychometric constant, $\mathrm{kPa}^{\circ} \mathrm{C}^{-1}$. 
The effect of soil water stress on crop ET is accounted by multiplying the crop coefficient by the water stress coefficient $\left(K_{s}\right)$, which is given by the following equation:

$$
\mathrm{K}_{\mathrm{s}}=\frac{\mathrm{TAW}-\mathrm{D}_{\mathrm{r}}}{\text { TAW-RAW }}=\frac{\text { TAW }-\mathrm{D}_{\mathrm{r}}}{(1-\mathrm{p}) \mathrm{TAW}}
$$

\section{Where:}

TAW is the total available water in the root zone depth $(\mathrm{mm})$, RAW is the readily available water in the root zone $(\mathrm{mm}), \mathrm{RAW}=\mathrm{p}^{*} \mathrm{TAW}$, $\mathrm{p}$ is the fraction of TAW that a crop can extract from the root zone without water stress (assumed as 0.45) and

$D_{r}$ is the root zone depletion in the root zone $(\mathrm{mm})$

The total available water in the root zone is estimated as follows:

$\mathrm{TAW}=1000\left(\theta_{\mathrm{FC}}-\theta_{\mathrm{WP}}\right) \mathrm{Z}_{\mathrm{r}}$

Where:

$\theta_{\mathrm{FC}}$ is the field capacity $\left(\mathrm{m}^{3} / \mathrm{m}^{3}\right)$,

$\theta_{W P}$ is the permanent wilting point $\left(\mathrm{m}^{3} / \mathrm{m}^{3}\right)$ and

$Z_{r} \quad$ is the effective rooting depth $(\mathrm{m})$

The adjusted $\mathrm{K}_{\mathrm{c}}$ due to water stress is:

$\mathrm{K}_{\mathrm{c}-\mathrm{adj}}=\mathrm{K}_{\mathrm{s}} \times \mathrm{K}_{\mathrm{c}}$ for single crop coefficient

$\mathrm{K}_{\mathrm{c}-\mathrm{adj}}=\mathrm{K}_{\mathrm{s}} \times \mathrm{K}_{\mathrm{cb}}+\mathrm{K}_{\mathrm{e}}$ for dual crop coefficient

(9)

The field crop evapotranspiration $\left(E T_{C}\right)$ was calculated using the following equation (10):

$$
\mathrm{ET}_{\mathrm{C}}=\mathrm{P}+\mathrm{I}-\mathrm{D}-\mathrm{R} \pm \Delta \mathrm{S}
$$

Where $E T_{C}$ is the crop evapotranspiration $(\mathrm{mm}), P$ is precipitation $(\mathrm{mm}), \mathrm{I}$ is irrigation $(\mathrm{mm}), D$ is the water drained $(\mathrm{mm}), R$ is the runoff $(\mathrm{mm})$ and $\Delta S$ represents the changes in soil water storage during the growth period. $D$ and $R$ were considered as zero because of control irrigation. The changes in soil moisture were estimated with soil moisture measurements at different depths.

\section{Development of Crop Coefficient}

The $\mathrm{K}_{\mathrm{c}}$ values were developed for sunflower crop using $\mathrm{ET}_{0}$ estimates from FAO-PM method. To compute $\mathrm{K}_{\mathrm{c}}$ based on crop development stage, it is important to establish the length of different crop growth stages (Table 4). Allen et al. (1998) divided the crop cycle into four stages: initial stage (marked with about $10 \%$ of plant cover), development stage (marked with the growth of plant $10 \%$ ground cover to effective cover i.e., flowering), mid-season stage (effective cover to start maturity) and late season stage (Start of maturity to harvest). 


\section{Sunflower crop coefficient $\left(K_{c}\right)$}

The crop coefficients of the sunflower during the different growth stages according to the standard FAO methodology were presented in Table (5).

Table(5). Sunflower crop coefficient at growing periods (Doorenbose and Kassam, 1986)

\begin{tabular}{lcc}
\hline \multicolumn{1}{c}{ Growth stages } & Period length (days) & $\mathbf{K}_{\mathbf{c}}$ value \\
\hline Initial & 20 & 0.35 \\
Development & 25 & 0.75 \\
Midseason & 38 & 1.10 \\
Late season & 20 & 0.35 \\
\hline
\end{tabular}

Crop coefficient obtained for four growth stages of crop growing periods. The four growth stages of crop growing periods are as follows:

1. Initial period (planting to $10 \%$ ground cover)

2. Crop development ( $10 \%$ ground cover to effective cover i.e., flowering)

3. Mid-season (Effective cover to start maturity)

4. Late-season (Start of maturity to harvest)

The calculation procedure for crop evapotranspiration (ETc) consists of:

1. identifying the crop growth stages, determining their lengths, and selecting the corresponding $\mathrm{K}_{\mathrm{c}}$ coefficients;

2. adjusting the selected $\mathrm{K}_{\mathrm{c}}$ coefficients for frequency of wetting or climatic conditions during the stage;

3. constructing the crop coefficient curve (allowing one to determine $\mathrm{K}_{\mathrm{c}}$ values for any period during the growing period); and

4. calculating $\mathrm{ET}_{\mathrm{c}}$ as the product of $E \mathrm{~T}_{\mathrm{o}}$ and $\mathrm{K}_{\mathrm{c}}$.

\section{Crop coefficient (field approach)}

The single crop coefficient ( $\mathrm{K}_{\mathrm{c}}$ single) was defined as the ratio of the measured $E T_{C}$ by field soil moisture measurement to the $E T_{0}$ estimated by the $F A O$ Penman -Monteith equation (Allen et al., 1998) under standard condition as follows:

$$
\mathrm{K}_{\text {c-single }}=\frac{\mathrm{ET}_{\mathrm{c}}}{\mathrm{ET}_{0}}
$$

The dual crop coefficient under standard conditions can be presented as:

$\mathrm{K}_{\mathrm{c} \text {-dual }}=\frac{\mathrm{ET}_{\mathrm{c}}}{\mathrm{ET}_{0}}=\mathrm{K}_{\mathrm{cb}}+\mathrm{K}_{\mathrm{e}}$ 
Where:

$\mathrm{K}_{\mathrm{cb}}$ is the basal crop coefficient and $\mathrm{K}_{\mathrm{e}}$ is the soil evaporation coefficient.

Therefore, crop development and its characteristics were recorded during the growing season to separate the individual growing stages of sunflower being the initial, development, mid and end stages.

\section{Crop coefficient (FAO approach)}

\section{Single crop coefficient}

The values for large number of crops are presented in Allen et al. (1998). They are based on average conditions in sub-humid climate. FAO has presented a correction equation to normalize the $\mathrm{K}_{\mathrm{c}}$ value for other places with different climatological and soil conditions.

The value of $\mathrm{K}_{\mathrm{c}}$ ini can be estimated from Figures 29 and 30 (Allen et al., 1998) as follows:

$\mathrm{K}_{\mathrm{c} \text { ini }}=\mathrm{K}_{\text {cini }}\left(\right.$ Fig. 29) $+\frac{(\mathrm{I}-10)}{(40-10)}\left[\mathrm{K}_{\text {cini }}\left(\right.\right.$ Fig 30)-K $\mathrm{K}_{\text {cini }}($ Fig 29) $]$

Where:

$\mathrm{K}_{\mathrm{c} \text { ini }}$ is the value for $\mathrm{K}_{\mathrm{c} \text { ini }}$ from Figure 29 (Allen et al., 1998)

$\mathrm{K}_{\mathrm{c} \text { ini }}$ is the value for $\mathrm{K}_{\mathrm{c} \text { ini }}$ from Figure 30 (Allen et al., 1998)

$\mathrm{I}$ is the average infiltration depth $(\mathrm{mm})$

The values 10 and 40 in Equation are the average depths of infiltration(mm) upon which Figures 29 and 30 (Allen et al., 1998) are based.

Drip irrigation wet only a fraction of the soil surface, the fraction of the surface wetted, $\mathrm{f}_{\mathrm{w}}$ ranged from 0.3 to 0.4 . The $\mathrm{Kc}_{\text {ini }}$ can be calculated from the following equation:

$$
\mathrm{K}_{\text {cini }}=\mathrm{f}_{\mathrm{w}} \times \mathrm{K}_{\text {cini }}(\mathrm{Tab}, \text { Fig })
$$

Where:

$f_{w}$ is the fraction of surface wetted by irrigation $(0-1), 0.3$ for drip irrigation $\mathrm{K}_{\mathrm{c} \text { ini }}(\mathrm{Tab}, \mathrm{Fig})$ is the value of $\mathrm{K}_{\mathrm{c}}$ ini from Table 12 or Figure 29 or 30 (Allen et al., 1998).

The value of $\mathrm{K}_{\mathrm{c} \text { mid, }}$ specific adjustment in climate where $\mathrm{RH}_{\min }$ differ from $45 \%$ or where $\mathrm{U}_{2}$ is larger or smaller than $2.0 \mathrm{~m} / \mathrm{s}$ was used. The value of $\mathrm{K}_{\mathrm{c} \text { mid }}$ is adjusted as:

$$
\mathrm{K}_{\mathrm{c}-\mathrm{mid}}=\mathrm{K}_{\mathrm{c}-\mathrm{mid}}(\mathrm{Tab})+\left[0.04\left(\mathrm{U}_{2}-2\right)-0.004\left(\mathrm{RH}_{\text {min }}-45\right)\right]\left[\frac{\mathrm{h}}{3}\right]^{0.3}
$$

Where:

$\mathrm{K}_{\mathrm{c} \text { mid }}(\mathrm{Tab})$ is the value of $\mathrm{Kc}$ mid taken from FAO Table (12), Allen et al. (1998) 
$\mathrm{U}_{2}$ is the mean value of daily wind speed at $2 \mathrm{~m}$ height over the soil surface during the mid- season growth stage $(\mathrm{m} / \mathrm{s})$ for $1 \mathrm{~m} / \mathrm{s} \quad<=U_{2}<=6 \mathrm{~m} / \mathrm{s}$.

$\mathrm{RH}_{\min }$ is the mean value for daily minimum relative humidity during the mid-season growth stage $9 \%$ ), for $20 \%<=\mathrm{RH}_{\min }<=80 \%$.

$\mathrm{h}$ is the mean plant height during the mid-season growth stage $(\mathrm{m})$ for $0.1 \mathrm{~m}<\mathrm{h}<$ $10 \mathrm{~m}$.

The value of $\mathrm{K}_{\mathrm{c} \text { end }}$ is adjusted as:

$\mathrm{K}_{\mathrm{c} \text {-end }}=\mathrm{K}_{\mathrm{c} \text {-nd }}(\mathrm{Tab})+\left[0.04\left(\mathrm{U}_{2}-2\right)-0.004\left(\mathrm{RH}_{\min }-45\right)\right]\left[\frac{\mathrm{h}}{3}\right]^{0.3}$

\section{Dual crop coefficient}

The crop coefficient is divided into two parts (Equation). The first part is the basal crop coefficient $\left(\mathrm{K}_{\mathrm{cb}}\right)$ that refers to the crop transpiration component of $E T_{c}$ when the soil surface is dry but transpiration is occurring at a potential rate, i.e., water is not limiting transpiration (Allen et al., 1998). The second part is the soil evaporation coefficient $\mathrm{K}_{\mathrm{e}}$ that describes the soil evaporation component of $\mathrm{ET}_{\mathrm{c}}$.

Similar to the single crop coefficient approach, a correction equation is used to determine $\mathrm{K}_{\mathrm{cb}}$ in mid- and end-season stages of sunflower through the following equations:

$$
\begin{aligned}
& \mathrm{K}_{\mathrm{cb}-\mathrm{mid}}=\mathrm{K}_{\mathrm{cb}-\mathrm{mid}}(\mathrm{Tab})+\left[0.04\left(\mathrm{U}_{2}-2\right)-0.004\left(\mathrm{RH}_{\min }-45\right)\right]\left[\frac{\mathrm{h}}{3}\right]^{0.3} \\
& \mathrm{~K}_{\mathrm{cb}-\text { end }}=\mathrm{K}_{\mathrm{cb}-\mathrm{end}}(\mathrm{Tab})+\left[0.04\left(\mathrm{U}_{2}-2\right)-0.004\left(\mathrm{RH}_{\text {min }}-45\right)\right]\left[\frac{\mathrm{h}}{3}\right]^{0.3}
\end{aligned}
$$

The soil evaporation coefficient $\left(\mathrm{K}_{\mathrm{e}}\right)$ depends on several parameters such as the irrigation period, irrigation depth, soil properties, wetting area, and crop development.

When the soil is wet, evaporation from the soil surface occurs at maximum rate. Therefore, the dual crop coefficient can never exceed a maximum value, $\mathrm{K}_{\mathrm{c}}$ $\max$. The $\mathrm{K}_{\mathrm{e}}$ can be determined as:

$$
\mathrm{K}_{\mathrm{e}}=\mathrm{K}_{\mathrm{r}}\left(\mathrm{K}_{\mathrm{c} \max }-\mathrm{K}_{\mathrm{cb}}\right)<=\mathrm{f}_{\mathrm{ew}} \mathrm{K}_{\mathrm{c} \max }
$$

Where:

$\mathrm{K}_{\mathrm{e}}$ is the soil evaporation coefficient (-)

$\mathrm{K}_{\mathrm{cb}}$ is the basal crop coefficient,

$\mathrm{K}_{\mathrm{c} \text { max }}$ is the maximum value of $\mathrm{Kc}$ following irrigation,

$\mathrm{K}_{\mathrm{r}}$ is the evaporation reduction coefficient depends on the cumulative depth of water depleted from the topsoil,

$f_{e w}$ is the fraction of the soil that is both exposed and wetted

The $\mathrm{K}_{\mathrm{c} \text { max }}$ range from 1.05 to 1.30 and can be expressed as: 


$$
\begin{aligned}
& \left.\mathrm{K}_{\mathrm{c} \max }=\max \left\langle\left[1.2+\left(0.04\left(\mathrm{U}_{2}-2\right)-0.004\left(\mathrm{RH}_{\text {min }}-45\right)\right)\left(\frac{\mathrm{h}}{3}\right)^{0.3}\right]\right\rangle,\left\{\mathrm{K}_{\mathrm{cb}}+0.05\right)\right\} \\
& \mathrm{K}_{\mathrm{r}}=\frac{\text { TEW-Di }}{\text { TEW-REW }}
\end{aligned}
$$

Where:

TEW is the maximum cumulative depth of evaporation (depletion) from the soil surface layer

REW is the readily evaporable water $(\mathrm{mm})$

$\mathrm{Di}$ is the cumulative depth of evaporation (depletion) from the soil surface layer.

$\mathrm{f}_{\mathrm{ew}}=\min \left(1-\mathrm{f}_{\mathrm{c}}, \mathrm{f}_{\mathrm{w}}\right)$

$1-f_{c}$ is the average exposed soil fraction not covered by vegetation (0.01-1), Table (6)

$f_{e w}$ is the average fraction of soil surface wetted by irrigation (0.01-1)

Table (6). Common values of fractions covered by vegetation ( $\mathrm{fc}$ ) and exposed sunlight(1-f $\left.f_{c}\right)$, Allen et al. (1998).

\begin{tabular}{lcc}
\hline \multicolumn{1}{c}{ Crop growth stage } & $\mathbf{f}_{\mathbf{c}}$ & $\mathbf{1 - f}_{\mathbf{c}}$ \\
\hline Initial stage (I) & $0.0-0.1$ & $1.0-0.9$ \\
Crop development stage (II) & $0.1-0.8$ & $0.9-0.2$ \\
Mid-season stage (III) & $0.8-1.0$ & $0.2-0.0$ \\
Late (end) season stage (IV) & $0.8-0.2$ & $0.2-0.8$ \\
\hline
\end{tabular}

\section{Experimental design}

A randomized complete block design (RCBD) with five treatments. Irrigation treatments were conducted using a drip irrigation system. The drip irrigation system was divided into three plots (replicates), and each plot had one valve.

\section{Statistical analysis}

Seed and oil yields were analyzed using a single-factor analysis of variance (ANOVA), and multiple comparisons were done for significant effects among treatment with the least significant difference (LSD) test by SPSS (Windows V18). The analysis was performed at 0.05 probability level of significant. The Duncan's Multiple Range Test was used for comparisons among different sources of variance. 


\section{RESULTS AND DISCUSSION}

The sunflower growing periods were divided to four stages; initial, development, mid- and late growing stages. The sunflower planting period started on 28 April and was finished on 8 August. Table (7) illustrates the length of growing stages, crop coefficient $\left(\mathrm{K}_{\mathrm{c}}\right)$ and reference evapotranspiration $\left(\mathrm{ET}_{0}\right)$.

Table (7). Growth period, crop coefficient and reference evapotranspiration of sunflower

\begin{tabular}{lccc}
\hline \multicolumn{1}{c}{ Growth stage } & $\begin{array}{c}\text { Period length } \\
\text { (days) }\end{array}$ & $\begin{array}{c}\mathbf{K}_{\mathbf{c}} \\
\text { value }\end{array}$ & $\begin{array}{c}\mathbf{E T}_{\mathbf{0}} \\
\mathbf{( m \mathbf { m } )}\end{array}$ \\
\hline Initial stage (I) & 20 & 0.35 & 87.2 \\
Crop development stage (II) & 25 & 0.75 & 142.7 \\
Mid-season stage (III) & 38 & 1.15 & 182.0 \\
Late (end) season stage (IV) & 20 & 0.35 & 93.5 \\
\hline Total & 103 & & 505.4 \\
\hline
\end{tabular}

\section{Reference Evapotranspiration (ETo)}

The daily $\mathrm{ET}_{0}$ was calculated according to the FAO Penman-Monteith equation (Allen et al., 1998). During the sunflower growing season, the daily $\mathrm{ET}_{0}$ varied from 3.21 to $9.97 \mathrm{~mm} /$ day with an average of $4.91 \mathrm{~mm} /$ day and total value of $505.4 \mathrm{~mm} /$ season. The variation of $\mathrm{ET}_{0}$ during the growing period is illustrated in Figure (1).

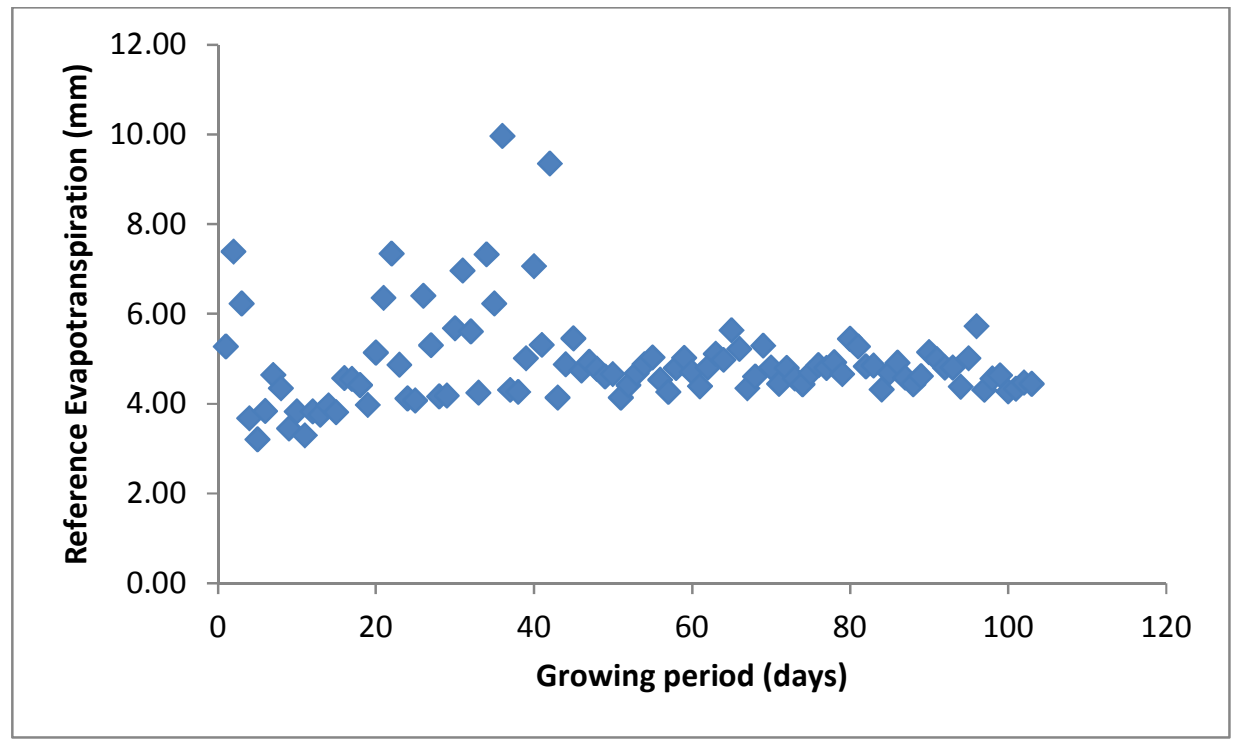

Fig. (1). Daily variation of reference evapotranspiration during growing period of sunflower 


\section{Crop evapotranspiration $\left(E T_{c}\right)$ of sunflower}

\section{FAO single crop coefficient $\left(\mathrm{K}_{\mathrm{c}}\right)$}

The daily sunflower evapotranspiration $\left(E T_{c}\right)$ using standard single crop coefficient is illustrated in Figure (2).

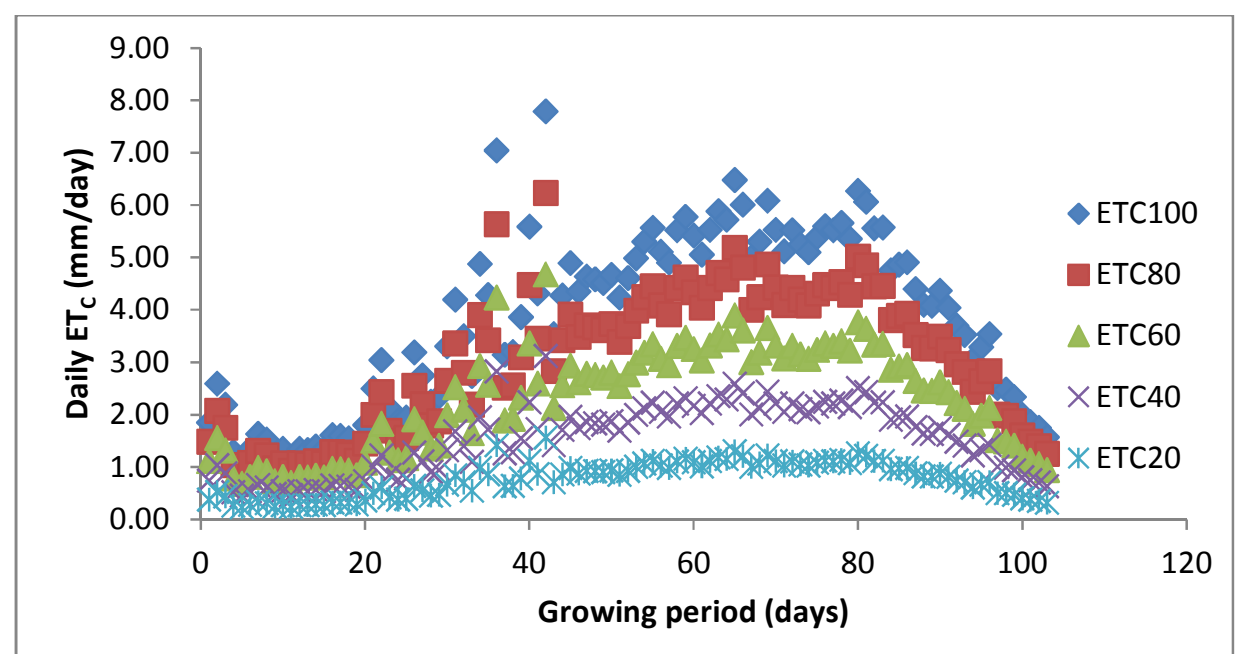

Figure (2). Daily variation of sunflower crop evapotranspiration $\left(E T_{c}\right)$ with irrigation regimes using single crop coefficient.

Table (8) shows the sunflower crop evapotranspiration during initial, development, mid- and late growth stages according FAO standard approach. The crop evapotranspiration was decreased as water regime (\% of $E T_{0}$ ) decreased. The crop coefficient was $0.35,1.15$ and 0.35 for initial, mid- and late growth stages as mentioned by Allen et al. (1998).

Table (8). Sunflower crop evapotranspiration( $\mathrm{mm} / \mathrm{ha})$ of growth stages with irrigation regimes (Single crop coefficient standard FAO approach)

\begin{tabular}{|c|c|c|c|c|c|c|c|}
\hline Growth stage & $\begin{array}{c}\mathrm{K}_{\mathrm{c}} \text { value } \\
\text { (standard } \\
\mathrm{FAO} \mathrm{K}_{\mathrm{c}} \text { ) }\end{array}$ & $\begin{array}{c}\mathrm{ET}_{0} \\
(\mathrm{~mm})\end{array}$ & $\begin{array}{c}100 \% \\
\mathrm{ET}_{0} \\
(\mathrm{~mm})\end{array}$ & $\begin{array}{l}80 \% \\
\mathrm{ET}_{0} \\
(\mathrm{~mm})\end{array}$ & $\begin{array}{l}60 \% \\
\mathrm{ET}_{0} \\
(\mathrm{~mm})\end{array}$ & $\begin{array}{c}40 \% \\
\mathrm{ET}_{0} \\
(\mathrm{~mm})\end{array}$ & $\begin{array}{c}20 \% \\
\mathrm{ET}_{0} \\
(\mathrm{~mm})\end{array}$ \\
\hline Initial stage (I) & 0.35 & 87.2 & 30.5 & 24.4 & 18.3 & 12.2 & 6.1 \\
\hline Crop development stage (II) & 0.75 & 142.7 & 110.2 & 88.2 & 66.1 & 44.1 & 22.0 \\
\hline Mid-season stage (III) & 1.15 & 182.0 & 209.3 & 167.4 & 125.6 & 83.7 & 41.9 \\
\hline Late (end) season stage (IV) & 0.35 & 93.5 & 68.5 & 54.8 & 41.1 & 27.4 & 13.7 \\
\hline Total $(\mathrm{mm})$ & & 505.4 & 418.5 & 334.8 & 251.1 & 167.4 & 83.7 \\
\hline
\end{tabular}


The seasonal sunflower crop evapotranspiration $\left(\mathrm{ET}_{\mathrm{c}}\right)$ according to standard FAO methodology were 418.5, 344.8, 251.1, 167.4 and $83.7 \mathrm{~mm}$ for $100,80,60$, 40 and $20 \% \mathrm{ET}_{0}$ irrigation regimes, respectively (Table 8 ).

The seasonal crop evapotranspiration $\left(\mathrm{ET}_{\mathrm{c}}\right)$ of sunflower according to single crop coefficient field approach were 466.2, 372.9, 279.9, 186.5 and $93.2 \mathrm{~mm}$ for $100,80,60,40$ and $20 \% \mathrm{ET}_{0}$ irrigation regimes, respectively (Table 9 ). The single crop coefficient was $0.58,0.89,1.19$ and 0.35 for initial, development, mid- and late growth stages under field conditions.

There are little differences between standard and field approach of crop coefficient, but the initial crop coefficient $\left(\mathrm{K}_{\mathrm{C}}\right.$ ini) is larger in field approach because of field conditions of the present experiment. Generally, crop coefficient depends on weather conditions, growth characteristics and ground cover of sunflower under field conditions.

Table (9). Sunflower actual crop evapotranspiration $(\mathrm{mm})$ of growth stages with irrigation regimes (single crop coefficient field approach)

\begin{tabular}{|c|c|c|c|c|c|c|c|}
\hline Growth stage & $\begin{array}{c}\mathrm{K}_{\mathrm{c}} \text { value } \\
\text { (Field } \\
\text { approach) }\end{array}$ & $\begin{array}{c}\mathrm{ET}_{0} \\
(\mathrm{~mm})\end{array}$ & $\begin{array}{c}100 \% \\
\mathrm{ET}_{0} \\
(\mathrm{~mm})\end{array}$ & $\begin{array}{l}80 \% \\
\mathrm{ET}_{0} \\
(\mathrm{~mm})\end{array}$ & $\begin{array}{c}60 \% \\
\mathrm{ET}_{0} \\
(\mathrm{~mm})\end{array}$ & $\begin{array}{l}40 \% \\
\mathrm{ET}_{0} \\
(\mathrm{~mm})\end{array}$ & $\begin{array}{c}20 \% \\
\mathrm{ET}_{0} \\
(\mathrm{~mm})\end{array}$ \\
\hline Initial stac & 0.58 & 87.2 & 50.6 & 40.5 & 30.4 & 20.2 & 10.1 \\
\hline Crop development stage (II) & 0.89 & 142.7 & 128.7 & 103.0 & 77.2 & 51.5 & 25.7 \\
\hline Mid-season stage (III) & 1.19 & 182.0 & 216.6 & 173.3 & 129.9 & 86.6 & 43.3 \\
\hline Late (end) season stage (IV) & 0.35 & 93.5 & 70.3 & 56.3 & 42.2 & 28.1 & 14.1 \\
\hline Total $(\mathrm{mm})$ & & 505.4 & 466.2 & 372.9 & 279.7 & 186.5 & 93.2 \\
\hline
\end{tabular}

\section{Basal crop coefficient $\left(\mathrm{K}_{\mathrm{cb}}\right)$}

The crop coefficient, soil evaporation and dual daily crop coefficient of sunflower crop were obtained during the growing period. The values of basal crop coefficient during sunflower growing period are shown in Table (10). The values were $0.32,0.69,1.05$ and 0.25 for initial, development, mid- and late growth stages according to FAO standard approach (Table 10). The basal crop coefficient (i.e., transpiration component) gradually increased as the highest value was obtained in the development growth stage. Thus, the transpiration value was decreased during late growing stage. The soil evaporation was differed according to the water regime, it reached $0.61,0.55,0.51,0.43$ and 0.34 for $100,80,60,40$ and $20 \%$ of $E T_{0}$. The seasonal crop evapotranspiration $\left(E T_{c}\right)$ of sunflower according to dual crop coefficient standard approach were 484.7, 377.7, 291.0, 184.4 and $99.0 \mathrm{~mm}$ for $100,80,60,40$ and $20 \% \mathrm{ET}_{0}$ irrigation regimes, respectively (Table 10). 
J. Adv. Agric. Res. (Fac. Agric. Saba Basha)

Table (10). Sunflower crop evapotranspiration $(\mathrm{mm})$ of growth stages with irrigation regimes (dual crop coefficient standard FAO approach)

\begin{tabular}{|c|c|c|c|c|c|c|c|}
\hline Growth stage & $\begin{array}{l}\mathrm{K}_{\mathrm{cb}} \text { value } \\
\text { (standard } \\
\text { approach) }\end{array}$ & $\begin{array}{c}\mathrm{ET}_{0} \\
(\mathrm{~mm})\end{array}$ & $\begin{array}{c}100 \% \\
\mathrm{ET}_{0} \\
(\mathrm{~mm})\end{array}$ & $\begin{array}{l}80 \% \\
\mathrm{ET}_{0} \\
(\mathrm{~mm})\end{array}$ & $\begin{array}{l}60 \% \\
\mathrm{ET}_{0} \\
(\mathrm{~mm})\end{array}$ & $\begin{array}{l}40 \% \\
\mathrm{ET}_{0} \\
(\mathrm{~mm})\end{array}$ & $\begin{array}{c}20 \% \\
\mathrm{ET}_{0} \\
(\mathrm{~mm})\end{array}$ \\
\hline Initial stage (I) & 0.32 & 87.2 & 58.4 & 45.7 & 36.7 & 24.3 & 14.1 \\
\hline Crop development stage (II) & 0.69 & 142.7 & 135.1 & 103.3 & 79.9 & 50.8 & 27.5 \\
\hline Mid-season stage (III) & 1.05 & 182.0 & 217.5 & 164.4 & 124.5 & 77.3 & 40.0 \\
\hline Late (end) season stage (IV) & 0.25 & 93.5 & 83.7 & 64.2 & 49.9 & 31.9 & 17.4 \\
\hline Total $(\mathrm{mm})$ & & 505.4 & 484.7 & 377.7 & 291.0 & 184.4 & 99.0 \\
\hline
\end{tabular}

The seasonal crop evapotranspiration $\left(\mathrm{ET}_{\mathrm{c}}\right)$ of sunflower according to dual crop coefficient field approach were 496.1, 388.9, 288.8, 188.7 and $100.8 \mathrm{~mm}$ for $100,80,60,40$ and $20 \% \mathrm{ET}_{0}$ irrigation regimes, respectively (Table 10). The dual crop coefficient (field approach) was $0.35,0.69,1.09$ and 0.35 for initial, development, mid- and late growth stages (Table 11).

Table (11). Sunflower crop evapotranspiration $(\mathrm{mm})$ of growth stages with irrigation regimes (dual crop coefficient field approach)

\begin{tabular}{|c|c|c|c|c|c|c|c|}
\hline Growth stage & $\begin{array}{l}\mathrm{K}_{\mathrm{cb}} \text { value } \\
\text { (field } \\
\text { approach) }\end{array}$ & $\begin{array}{c}E T_{0} \\
(\mathrm{~mm})\end{array}$ & $\begin{array}{c}100 \% \\
\mathrm{ET}_{0} \\
(\mathrm{~mm})\end{array}$ & $\begin{array}{l}80 \% \\
\mathrm{ET}_{0} \\
(\mathrm{~mm})\end{array}$ & $\begin{array}{c}60 \% \\
\mathrm{ET}_{0} \\
(\mathrm{~mm})\end{array}$ & $\begin{array}{c}40 \% \\
\mathrm{ET}_{0} \\
(\mathrm{~mm})\end{array}$ & $\begin{array}{c}20 \% \\
\mathrm{ET}_{0} \\
(\mathrm{~mm})\end{array}$ \\
\hline Initial stage (I) & 0.35 & 87.2 & 58.6 & 47.1 & 37.7 & 24.9 & 14.3 \\
\hline Crop development stage (II) & 0.69 & 142.7 & 134.9 & 106.0 & 81.7 & 51.8 & 27.9 \\
\hline Mid-season stage (III) & 1.09 & 182.0 & 216.6 & 168.2 & 127.1 & 78.8 & 40.6 \\
\hline Late (end) season sta & 0.35 & 93.5 & 86.0 & 67.7 & 52.3 & 33.3 & 18.0 \\
\hline Total $(\mathrm{mm})$ & & 505.4 & 496.1 & 388.9 & 298.8 & 188.7 & 100.8 \\
\hline
\end{tabular}

The seasonal crop evapotranspiration $\left(E T_{c}\right)$ of sunflower according to Irrigation field approach was 496.0, 398.1, 299.6, 200.1 and $103.3 \mathrm{~mm}$ for 100, 80, 60,40 and $20 \% \mathrm{ET}_{0}$ irrigation regimes, respectively (Table 12). The crop coefficient was $0.51,0.90,1.50$ and 0.54 for initial, development, mid- and late growth stages under field conditions.

Table (12). Sunflower crop evapotranspiration $(\mathrm{mm})$ of growth stages with irrigation regimes (Field Irrigation approach)

\begin{tabular}{|c|c|c|c|c|c|c|c|}
\hline Growth stage & $\begin{array}{c}\mathrm{K}_{\mathrm{c}} \text { value } \\
\text { (field } \\
\text { approach) }\end{array}$ & $\begin{array}{c}\mathrm{ET}_{0} \\
(\mathrm{~mm})\end{array}$ & $\begin{array}{c}100 \% \\
\mathrm{ET}_{0} \\
(\mathrm{~mm})\end{array}$ & $\begin{array}{l}80 \% \\
\mathrm{ET}_{0} \\
(\mathrm{~mm})\end{array}$ & $\begin{array}{c}60 \% \\
\mathrm{ET}_{0} \\
(\mathrm{~mm})\end{array}$ & $\begin{array}{l}40 \% \\
\mathrm{ET}_{0} \\
(\mathrm{~mm})\end{array}$ & $\begin{array}{l}20 \% \\
\mathrm{ET}_{0} \\
(\mathrm{~mm})\end{array}$ \\
\hline Initial stage (I) & 0.51 & 87.2 & 44.2 & 38.4 & 35.7 & 28.4 & 19.5 \\
\hline Crop development stage (II) & 0.90 & 142.7 & 128.4 & 104.0 & 75.3 & 50.3 & 22.5 \\
\hline Mid-season stage (III) & 1.50 & 182.0 & 272.5 & 217.0 & 162.8 & 106.3 & 53.2 \\
\hline Late (end) season stage (IV) & 0.54 & 93.5 & 50.9 & 38.7 & 25.9 & 15.1 & 8.1 \\
\hline Total & & 505.4 & 496.0 & 398.1 & 299.6 & 200.1 & 103.3 \\
\hline
\end{tabular}

Vol. 21(2), 2016 
The daily sunflower crop coefficient can be calculated by the best fitted polynomial equation (Table 13):

$\mathrm{K}_{\mathrm{c}}$-single $($ standard $)=7.0 \mathrm{E}-08 \mathrm{DAP}^{4}-2.0 \mathrm{E}-05 \mathrm{DAP}^{3}+0.0015 \mathrm{DAP}^{2}-0.0184 \mathrm{DAP}+0.3783\left(\mathrm{R}^{2}=0.9700\right)$

$\mathrm{K}_{\mathrm{c}}$-single $($ field $)=3.0 \mathrm{E}-08 \mathrm{DAP}^{4}-1.0 \mathrm{E}-05 \mathrm{DAP}^{3}+0.001 \mathrm{DAP}^{2}-0.0113 \mathrm{DAP}+0.5913\left(\mathrm{R}^{2}=0.9688\right)$

$\mathrm{K}_{\mathrm{cb}}$-dual(standard $)=5.0 \mathrm{E}-08 \mathrm{DAP}^{4}-2.0 \mathrm{E}-05 \mathrm{DAP}^{3}+0.0013 \mathrm{DAP}^{2}-0.0159 \mathrm{DAP}+0.3427\left(\mathrm{R}^{2}=0.9695\right)$

$\mathrm{K}_{\mathrm{cb}}$-dual(field $)=6.0 \mathrm{E}-08 \mathrm{DAP}^{4}-2.0 \mathrm{E}-05 \mathrm{DAP}^{3}+0.0014 \mathrm{DAP}^{2}-0.017 \mathrm{DAP}+0.3762\left(\mathrm{R}^{2}=0.9695\right)$

$\mathrm{K}_{\mathrm{c}}$ (field irrigation) $=8.0 \mathrm{E}-08 \mathrm{DAP} \mathrm{P}^{4}-2.0 \mathrm{E}-05 \mathrm{DAP}^{3}+0.0017 \mathrm{DAP}^{2}-0.0185 \mathrm{DAP}+0.5215 \quad\left(\mathrm{R}^{2}=0.9671\right)$

Where DAP is the days after planting

Table (13). Crop coefficient during growth stages according to different approaches

\begin{tabular}{lccc}
\hline \multicolumn{1}{c}{ Methods } & Initial & Mid- & Late \\
\hline Single crop coefficient standard approach $\left(\mathrm{K}_{\mathrm{c}}\right)$ & 0.35 & 1.15 & 0.35 \\
Single crop coefficient field approach $\left(\mathrm{K}_{\mathrm{c} \text { adj }}\right)$ & 0.58 & 1.19 & 0.35 \\
Basal crop coefficient standard approach $\left(\mathrm{K}_{\mathrm{cb}}\right)$ & 0.32 & 1.05 & 0.25 \\
Basal crop coefficient field $\left(\mathrm{K}_{\mathrm{cb}}\right.$ adj $)$ & 0.35 & 1.09 & 0.35 \\
Field irrigation approach $\left(\mathrm{K}_{\mathrm{c}}\right)$ & 0.51 & 1.50 & 0.54 \\
\hline
\end{tabular}

The results indicated that seasonal sunflower evapotranspiration $(\mathrm{mm})$ has higher value with field irrigation approach and the lower value was for standard FAO single approach. The seasonal evapotranspiration (single crop coefficient approach) was less value than the seasonal evapotranspiration of dual crop coefficient approach.

The seasonal water requirements for sunflower crop with considering the irrigation and soil practices are illustrated in Table (14). The results indicated that water requirements of sunflower growing season were higher with irrigation approach and lower with single crop coefficient approach.

Comparison of the measured single crop coefficient with standard values of FAO showed that, the measured $\mathrm{K}_{\mathrm{c}}$ value at the initial stage was higher than the FAO standard value (by about $74.3 \%$ higher). The $\mathrm{K}_{\mathrm{c} \text {-ini }}$ greatly depends on the evaporating power of the atmosphere $\left(\mathrm{ET}_{0}\right)$, the water supply during a wetting event and the time interval between wetting events. Consequently, the $\mathrm{K}_{\mathrm{c} \text {-ini }}$ is influenced by the different irrigation strategies and soil practices.

Therefore, field management in the present study may not similar to the FAO-56 conditions. The FAO's predicted $\mathrm{K}_{\mathrm{c}}$ may not predict the evapotranspiration that occurs in the initial growing stage. The measured value of late stage $\left(\mathrm{K}_{\mathrm{c} \text {-end }}\right)$ is larger than proposed value of FAO-56 by about $11.42 \%$ (Table 15). 
Table (14). Sunflower water requirements $\left(\mathrm{m}^{3} / \mathrm{ha}\right)$ with irrigation regimes

\begin{tabular}{|c|c|c|c|c|c|}
\hline Growth stage & $\begin{array}{c}100 \% \\
\mathrm{ET}_{0}\left(\mathrm{~m}^{3} / \mathrm{ha}\right)\end{array}$ & $\begin{array}{c}80 \% \\
E T_{0}\left(m^{3} / h a\right)\end{array}$ & $\begin{array}{c}60 \% \\
E_{0}\left(m^{3} / h a\right)\end{array}$ & $\begin{array}{c}40 \% \\
E_{0}\left(m^{3} / h a\right)\end{array}$ & $\begin{array}{c}20 \% \\
E T_{0}\left(\mathrm{~m}^{3} / \mathrm{ha}\right)\end{array}$ \\
\hline \multicolumn{6}{|c|}{ single crop coefficient standard FAO approach } \\
\hline Initial stage (I) & 378.1 & 302.5 & 226.9 & 151.2 & 75.6 \\
\hline Crop development stage (II) & 1364.7 & 1091.8 & 818.8 & 545.9 & 272.9 \\
\hline Mid-season stage (III) & 2591.8 & 2073.4 & 1555.1 & 1036.7 & 518.4 \\
\hline Late (end) season stage (IV) & 848.6 & 678.9 & 509.2 & 339.5 & 169.7 \\
\hline Total water requirements & 5183.3 & 4146.6 & 3110.0 & 2073.3 & 1036.7 \\
\hline \multicolumn{6}{|c|}{ single crop coefficient field approach } \\
\hline Initial stage (I) & 626.6 & 501.3 & 376.0 & 250.6 & 125.3 \\
\hline Crop development stage (II) & 1593.8 & 1275.1 & 956.3 & 637.5 & 318.8 \\
\hline Mid-season stage (III) & 2682.0 & 2145.6 & 1609.2 & 1072.8 & 536.4 \\
\hline Late (end) season stage (IV) & 870.8 & 696.7 & 522.5 & 348.3 & 174.2 \\
\hline Total water requirements & 5773.2 & 4618.6 & 3463.9 & 2309.3 & 1154.6 \\
\hline \multicolumn{6}{|c|}{ dual crop coefficient standard approach } \\
\hline Initial stage (I) & 723.4 & 566.0 & 455.0 & 301.4 & 174.6 \\
\hline Crop development stage (II) & 1673.4 & 1279.8 & 989.3 & 629.1 & 340.0 \\
\hline Mid-season stage (III) & 2693.7 & 2036.3 & 1541.6 & 957.8 & 495.8 \\
\hline Late (end) season stage (IV) & 1036.1 & 795.0 & 618.1 & 395.5 & 216.1 \\
\hline Total water requirements & 6126.6 & 4677.0 & 3604.0 & 2283.9 & 1226.5 \\
\hline \multicolumn{6}{|c|}{ (dual crop coefficient field approach } \\
\hline Initial stage (I) & 726.0 & 582.9 & 466.7 & 307.9 & 177.2 \\
\hline Crop development stage (II) & 1670.5 & 1312.2 & 1011.8 & 641.6 & 345.0 \\
\hline Mid-season stage (III) & 2682.0 & 2083.1 & 1574.0 & 975.9 & 503.0 \\
\hline Late (end) season stage (IV) & 1065.1 & 837.9 & 647.8 & 412.0 & 222.7 \\
\hline Total water requirements & 6143.6 & 4816.0 & 3700.3 & 2337.4 & 1247.9 \\
\hline \multicolumn{6}{|c|}{ field irrigation approach } \\
\hline Initial stage (I) & 547.7 & 475.2 & 441.9 & 351.7 & 241.5 \\
\hline Crop development stage (II) & 1590.1 & 1287.9 & 932.5 & 622.9 & 278.6 \\
\hline Mid-season stage (III) & 3374.6 & 2687.3 & 2016.1 & 1316.4 & 658.8 \\
\hline Late (end) season stage (IV) & 630.3 & 479.6 & 320.2 & 187.2 & 100.3 \\
\hline Total water requirements & 6142.7 & 4930.1 & 3710.7 & 2478.3 & 1279.3 \\
\hline
\end{tabular}




\section{Table (15). Seasonal water requirements of sunflower (\%) as related to single crop coefficient (FAO standard)}

\begin{tabular}{|c|c|c|c|c|c|}
\hline Methods & $100 \% \mathrm{ET}_{0}$ & $80 \% \mathrm{ET}_{0}$ & $60 \% E T_{0}$ & $40 \% \mathrm{ET}_{0}$ & $20 \% \mathrm{ET}_{0}$ \\
\hline Single standard & 100.00 & 100.00 & 100.00 & 100.00 & 100.00 \\
\hline Single field & 111.38 & 111.38 & 111.38 & 111.38 & 111.38 \\
\hline Dual standard & 118.20 & 112.79 & 115.89 & 110.16 & 118.31 \\
\hline Dual field & 115.80 & 112.80 & 115.88 & 110.14 & 118.27 \\
\hline Irrigation & 118.51 & 118.89 & 119.32 & 119.53 & 123.40 \\
\hline
\end{tabular}

According to FAO-56 method corrected by equation (16 and 17), the sunflower $\mathrm{K}_{\mathrm{cb}}$ values were 0.32, 1.05 and 0.25 for initial, mid- and late-season stages, respectively. Actually, the measured values of $\mathrm{K}_{\mathrm{cb}}(0.35,1.09$ and 0.35 , respectively) were similar to the standard $\mathrm{FAO}$ method values. The $\mathrm{K}_{\mathrm{cb}}$ values are correlated with crop variety, cultivation pattern, crop coverage, soil practices and also the final crop yield. Different field treatments especially short irrigation intervals may keep the soil water content at optimum or higher value may lead to more or less evaporation occurring that affect the $\mathrm{K}_{\mathrm{e}}$ and $\mathrm{K}_{\mathrm{cb}}$ values. The field measurement to predict soil evaporation needs some practices to be more accurate to reduce the measured error.

The soil evaporation, $\mathrm{K}_{\mathrm{c}}$ and $\mathrm{K}_{\mathrm{cb}}$ coefficients are greatly affected by irrigation strategy, canopy coverage, local weather conditions, soil practices and irrigation system, therefore more investigation must be considering in determination of these parameters.

The higher values of sunflower water requirements for dual than single crop coefficients by about $3.1 \%$ may be due to more parameters affected the determination of dual $\mathrm{K}_{\mathrm{cb}}$ than single $\mathrm{K}_{\mathrm{c}}$. Therefore, the values of $\mathrm{K}_{\mathrm{c}}$ must be determined for different regions and different agricultural parameters, then local determination of crop coefficient has been recommended. The water requirements of sunflower with field irrigation approach were more than the dual crop coefficient approach by about $3.48 \%$ as mean of all water regimes.

The use of crop coefficients presented by FAO-56 (Allen et al., 1998) is common for use with crop water requirements estimation around the world. The present study showed that dual crop coefficient approach is located between the single crop coefficient and field irrigation approaches (₹3.2\%). Therefore, dual crop coefficient is the more precise estimation of crop water requirements of sunflower than single coefficient and field irrigation approaches. The presented values of single and dual $\mathrm{K}_{\mathrm{c}}$ will be useful in estimating sunflower water requirements of different crop growth stages and irrigation scheduling under semiarid regions such as the present experimental conditions. 
It appears that $\mathrm{ET}_{\mathrm{c}}$ estimation of sunflower crop is more accurate by dual crop coefficient approach than those produced by single crop coefficient approach because of using more parameters and taking the soil practices and crop characteristics in consideration. The basal crop coefficient values cannot be proposed for all climates and regions because of different climatic conditions and crop management practice under different regions.

The present study recommended that under the same conditions, the irrigation of sunflower crop must be done according to the dual crop coefficient approach because it is more accurate than single crop coefficient and close up to the field irrigation conditions. Also, the field measurement to predict soil evaporation needs some practices to be more accurate to reduce the measured error.

\section{REFERENCES}

Abid Karray, J., J. P. Lhomme, M. M. Masmoudi, and N. Ben Mechlia (2008). Water balance of the olive tree-annual crop association: A modeling approach. Agric. Water Manage. 95, 575-586.

Allen, R.G. (2000). Using the FAO-56 dual crop coefficient method over an irrigated region as part of an evapotranspiration inter-comparison study. J. Hydrol., 229: 27-41.

Allen, R.G., L. S. Pereira, D. Raes, M. Smith (1998). Crop EvapotranspirationGuidelines for Computing Crop Water Requirements, Irrigation and Drain, Paper No. 56. FAO, Rome, Italy, p. 300.

Allen, R.G., L. S. Pereira, M. Smith, D. Raes, and J. L. Wright (2005a). FAO-56 dual crop coefficient method for estimating evaporation from soil and application extensions. J. Irrig. Drain Eng. ASCE 131 (1), 2-13.

Allen, R.G., A. J. Clemmens, C. M. Burt, K. Solomon, and T. O'Halloran (2005b). Prediction accuracy for project-wide evapotranspiration using crop coefficient and reference evapotranspiration. J. Irrig. Drain Eng. ASCE, 131 (1), 24-36.

Blaney, H. F. and W. D. Criddle (1950). Determining water require ments in irrigated areas from climatological and irrigation data. U.S. Dept. Agric., Soil Cons. Serv., SCS-TP-96, 48 pp.

Braud, I., A. C. Dantas-Antonino, M. Vauclin, J. L. Thony, and P. Ruelle (1995). A simplesoil-plant-atmosphere transfer model (SiSPAT) development and field verification. J. Hydrol., 166: 213-250.

Brouwe, C. and M. Heibloem (1986). Irrigation water needs. Irrigation water management: Training Manual No. 3. Food and Agriculture Organization of United Nations. Rome, Italy.

Carter, M. R. and E. G. Gregorich (2008). Soil sampling and methods of Analysis. Second Edition. Canadian Society of soil Science; Boca Raton, FL: CRC Press, 1264 pages. 
Doorenbos, J. and A. H. Kassam (1979). Yield response to water: FAO Irrigation and Drainage paper 33. Food and Agriculture Organization of United Nations. Rome, Italy.

Doorenbos, J., and W. O. Pruitt (1977). Crop water requirements. FAO Irrigation and Drainage paper 24. Food and Agriculture Organization of United Nations. Rome, Italy.

Er-Raki S., G. Chehbouni N. Guemouria, B. Duchemin J. Ezzahar R. Hadria (2007). Combining FAO-56 model and ground-based remote sensing to estimate water consumptions of wheat crops in a semi-arid region. Agric. Water Manage., 87:41-54.

Er-Raki, S., A. Chehbouni and B. Duchemin (2010). Combining satellite remote sensing data with the FAO-56 dual approach for water use mapping in irrigated wheat fields of a semi-arid region. Remote Sens., 2 (1):375-387.

Er-Raki, S., A. Chehbouni, N. Guemouria, B. Duchemin, J. Ezzahar, R. Hadria, I. BenHadj (2006). Driven FAO-56 dual crop coefficient approach with remotely-sensed data for estimating water consumptions of wheat crops in a semi-arid region. The 2nd International Symposium on Recent Advances in Quantitative Remote Sensing: RAQRS'II, 25-29 September 2006, Valencia, Spain.

Er-Raki, S., A. Chehbouni, J. Hoedjes, J. Ezzahar, B. Duchemin, F. Jacob (2008). Improvement of FAO-56 method for olive orchards through sequential assimilation of Thermal infrared based estimates of ET. Agric. Water Manage., 95: 309-321.

González-Dugo, M.P. and L. Mateos (2008). Spectral vegetation indices for benchmarking water productivity of irrigated cotton and sugarbeet crops. Agric. Water Manage., 95(1):48-58.

Grattan S.R., W. George, W. Bowers, A. Dong, R.L. Snyder, J. Carrol (1998). New crop coefficients estimate water use of vegetables row crops, California Agriculture, 52 (1): 16-20.

Hunsaker, D. J., P.J. Jr Pinter, E. M. Barnes, B. A. Kimball (2003). Estimating cotton evapotranspiration crop coefficients with a multispectral vegetation index. Irrig. Sci., 22: 95-104.

Hunsaker, D. J., P.J. Jr Pinter, B.A. Kimball (2005). Wheat basal crop coefficients determined by normalized difference vegetation index. Irrig. Sci., 24: $1-14$.

Itenfisu, D. (1998). Adaptation of resistance-based evapotranspiration functions to row crops. Unpublished PhD dissertation, Dept. Biol. and Irrig. Engng, Utah State Univ., Logan, UT, 207pp.

Kang, S., B. Gu, T. Du, and J. Zhang (2003). Crop coefficient and ratio of transpiration to evapotranspiration of winter wheat and maize in a semi humid region. Agric.Water Manage., 59 (1): 239-254.

Karmeli, D. and J. Keller (1975). Trickle irrigation design. Rain-Brid Sprinkler Mfg. Co., Glendora, Calif. p. 133. 
Martınez-Cob, A. and J. M. Faci (2010). Evapotranspiration of a hedge-pruned olive orchard in a semiarid area of NE Spain. Agric. Water Manage., 97: 410-418.

Monteith, J. L. (1965). Evaporation and environment. The State and Movement of Water in Living Organisms, $19^{\text {th }}$ Symposium, Soc. Exp. Biol., 205-235.

Olioso, A., H. Chauki, D. Courault and J. P. Wigneron (1999). Estimation of evapotranspiration and photosynthesis by assimilation of remote sensing data into SVAT models. Remote Sens. Environ., 68: 341-356.

Paço, T. A., M. I. Ferreira, N. Conceiçao (2006). Peach orchard evapotranspiration in a sandy soil: Comparison between eddy covariance measurements and estimates by the FAO 56 approach. Agric. Water Manage., 85: 305-313.

Palomo, M.J., F. Moreno, J. E. Fernandez, A. Diaz- Espejo and I. F. Giron (2002). Determining water consumption in olive orchards using the water balance approach. Agric. Water Manage., 55: 15-35.

$$
\text { الملخص العربي }
$$

الاحتياجات المائية لزهرة الشمس باستخدام معاملات المحصول المفرد والمزدوج

$$
\begin{aligned}
& \text { أحمد سعد بندق * جمال عبد الناصر خليل * فتحي إبراهيم رضوان } \\
& \text { * قسم الأراضي والكيمياء الزراعية - كلية الزراعة سابا باثا - جامعة الاسكندرية } \\
& \text { ** قسم الانتاج النباتي - كلية الزراعة سابا باشا - جامعة الاسكندرية }
\end{aligned}
$$

أجريت تجربة حقلية لمحصول زهرة الثمس تحت نظام الري بالتتقيط فى المزرعة البحثبة لمحطة التجارب الزراعية لكلية

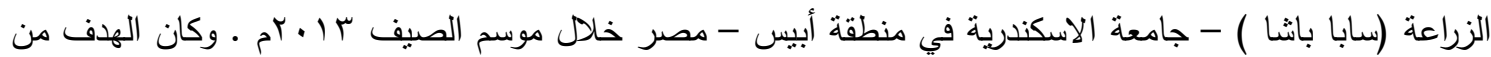
الدراسة هو ايجاد معامل المحصول لمحصول زهرة الثمس تحت نظام الرى بالتقبط - لتحقيق هذا الهذف تم ما يلي: 1- تحليل قدرة معامل المحصول المفرد والمزدوج المقترح من قبل الفاو لتقييم البخر -نتح والاحتياجات المائية المحلية. r- تقدير كمبة مياه الرى المطلوبة لمحصول زهرة الثمس تحت نظم الحساب المختلفة. وقد تم زراعة محصول زهرة

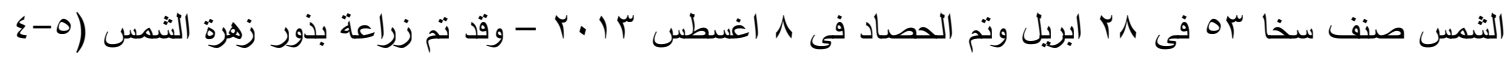

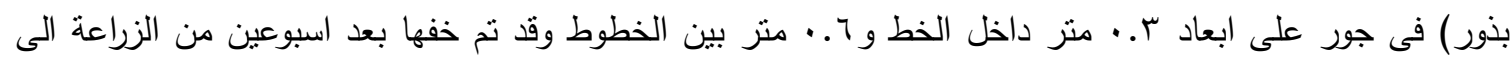

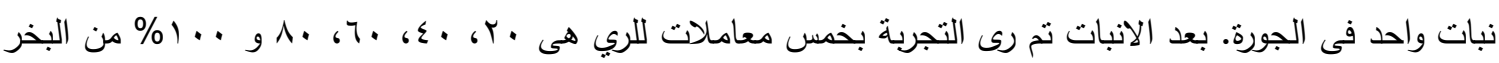

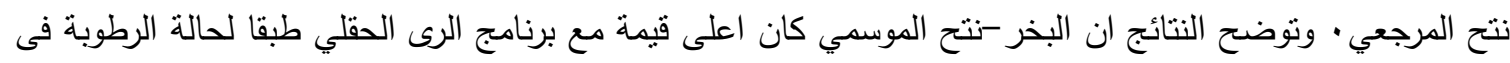

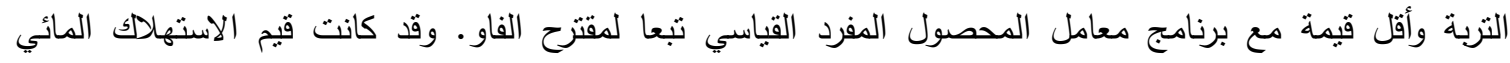
الموسمي بطريقة معامل المحصول المفرد القياسي أقل من قيمة الاستهلاك المائي الموسمى مع معامل المحصول

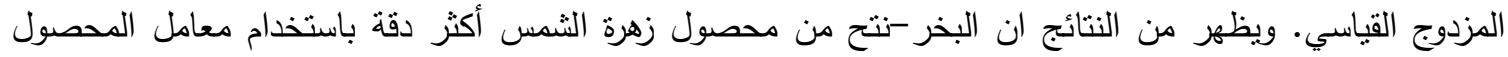


المزدوج عن استخدام معامل المحصول المفرد وذلك بسبب ارتباطه مع عوامل متعددة تأخذ فى الاعتبار خدمة التربة

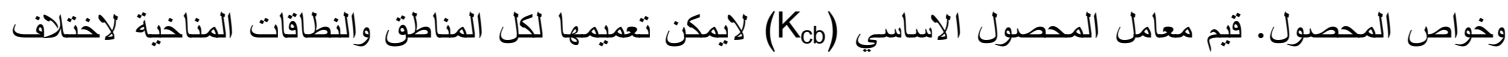

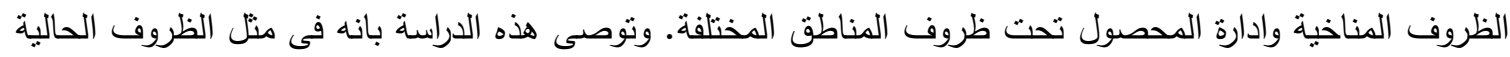

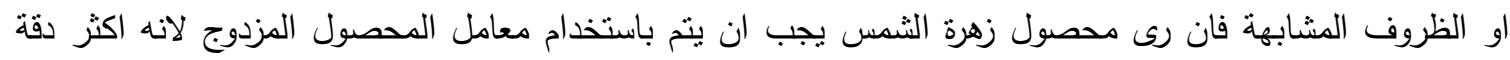
عن معامل المحصول المفرد وقريب من الظروف الحقلية. 